Logos Universality Mentality Education Novelty, Section: Social Sciences

ISSN: $2284-5747$ (print), ISSN: $2284-5747$ (electronic)

Covered in: CEEOL, Index Copernicus, Ideas RePEc, EconPapers, Socionet

\title{
THE VOICE OF RUSSIA AND THE ROMANIAN NEW MEDIA CONSUMERS
}

\section{Cătălin NEGOIŢĂ}

Logos Universality Mentality Education Novelty, Section:

Social Sciences, IV (1), 113-121

The online version of this article can be found at:

http://lumenjournals.com/social-sciences/

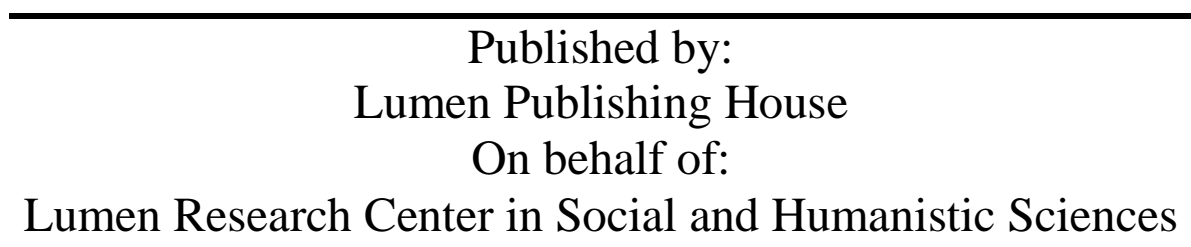




\title{
The Voice of Russia and the Romanian new media consumers
}

\section{Cătălin NEGOIȚ $\breve{A}^{1}$}

\begin{abstract}
Kremlin's mean of propaganda, since 1929, The Voice of Russia has been the trumpet of the Soviet Union's interests in the entire world. After the fall of the Iron Curtain, The Voice of Russia adapted to the new realities. Today, it is a public multimedia company. The V oice of Russia passed into the digital era, building a site, appealing to social networks in order to advance its visions. The policy of the company consists in aggressive promotion of the Russian interests abroad. The Voice of Russia's Facebook profile makes no exception. We will analyze the online media consumers' reaction to Moscow's posts.
\end{abstract}

\section{Keywords:}

The Voice of Russia, Moscow, Facebook, social networks, new media, aggressive promotion.

${ }^{1}$ Lecturer Ph.D, “Dunarea de Jos” University, Romania, catalin.negoita@gmail.com.

Negoita, C. (2015). The Voice of Russia and the Romanian new media consumers. Logos Universality Mentality Education Novelty, Section: Social Sciences, IV (1), 113-121. 
The choice regarding The Voice of Russia is not random and it is a consequence of the fact that among all Kremlin's means of propaganda it is the most interested in Romanian realities and the most virulent regarding the so-called enemies of Russia. Searching through Voice of Russia's website and Facebook page aimed to identify the method the persuasion and manipulation are generated, under the plea of emphasizing the immediate realities from the Russian Federation. Beyond the outward purpose, Voice of Russia canalized its efforts into changing Romanian listeners' vision regarding the European and EuroAtlantic institutions, regarding the United States, using all modern means of propaganda. The action was subtle: it did not insist on ameliorating the Federation's image on Romanian society, the staff realizing that this move takes a long period of gestation. In order to attract sympathy towards Moscow subtle methods were used: images of local beauties, picturesque landscapes, victories in sportive competition or cultural and scientific achievements.

I tried to analyze the way the Voice of Russia fought against Kremlin's enemies: right-wing parties and occidental institutions. For this exploratory research, I opted for a pragmatic approach, where I combined the longitudinal textual analysis with the quantitative and qualitative analysis. The record unit is the article, presented on Romania section. I counted the articles appeared in the studied period of time, obtaining the fallowing dates: July $2012-1$ article, August $2012-1$ article, September 2012 - no article, October 2012 - no article, November 2012 - 3 articles, December 2012 - 7 articles, January 2013 22 articles, February 2013 - 32 articles, March 2013 - 27 articles, April 2013 - 18 articles, May 2013 - 31 articles, June 2013 - 35 articles, July 2013 - 27 articles, August 2013 - 14 articles, September 2013 - 22 articles, October 2013 - 31 articles, November 2013 - 41 articles, December 2013 - 33 articles, January 2014 - 39 articles, February 2014 - 31 articles, March 2014 - 28 articles, April 2014 - 20 articles, May $2014-7$ articles, June $2014-8$ articles, July $2014-4$ articles, August 2014 - 3 articles, September 2014 - 3 articles, October 2014 - 5 articles, November 2014 - 5 articles, December 2014 - 3 articles; total number of articles 501 .

Voice of Russia (Голос России) is the former Radio Moscow, which began its broadcasts intended for foreign countries on 29 October 1929. Since the beginning of its existence it represented, an 
instrument of communist propaganda abroad, carried out as a cosmetic action of the rumpled picture of the Soviet Union, where terror and hunger they have been experienced since the success of the Bolshevik coup in 1917 (pompously named as the Great October Socialist Revolution), continuing with the devastating civil war and the repression against so-called enemies of the people.

Moscow Radio started broadcasting in Romanian language on 21 April 1941 on long and short wavelengths, therefore, nearly a year after the Soviet invasion of Bessarabia and Northern Bukovina. After the start of the German-Soviet war, in which Romania took part in order to free the lost territories, Soviet propaganda made by Radio Moscow has stepped up and the number of hours for broadcasts in Romanian increased significantly.

On the official website of Voice of Russia in Romanian, the presentation of the radio station stipulated the following: „That period was very difficult for our editorial team because Romania was a country allied with the fascist Germany. In our programs we have tried to show how unfortunate this alliance was for the country, and the misfortune and suffering brought by this unjust war."

The Voice of Russia goes with discretion beyond the Soviet occupation, the economic and political sacrifices imposed by Moscow, and makes a quantum leap until $70 \mathrm{~s}$, ,when editorial work has been affected by Ceausescu line, aimed at distancing from the USSR. At that time, an informational vacuum was in Romania, and Romanian citizens were listening to with interest our radio station broadcasts."

The presentation also mentions the period of perestroika, when the editorial team received a record number of letters from Romanian listeners and after that reminiscent of the last days of December 89: „We sincerely suffer for the fate of our Romanian friends. Our editorial staff has worked in those days of state of emergency with enthusiasm."

The end of the presentation is about the current period, during which ,spiritual contacts between Romanian editorial staff and our Romanian listeners have not been interrupted, and their painful problems, anxieties, their joys and misfortunes continue to be shared. Communication with them brings us great professional satisfaction."

From 29 March 2009, the Voice of Russia in Romanian ceased short and medium wavelengths radio programs and broadcasts only on the Internet. From the site presentation, we learn that „,contemporary 
radio station Voice of Russia broadcasts on the Internet in Russian and in other 38 foreign languages. Voice of Russia website, comprising over 500 headings, is read by Internet users from 110 countries. The Internet users have access to satellite broadcast, via mobile phone, through audio, video and multimedia files."

Facebook page of the Voice of Russia was activated on 10 January 2012. „We are glad to welcome you on the official website of the radio station Voice of Russia. From Moscow, Voice of Russia offers you the latest news from Russia and abroad"

The tasks of Voice of Russia, a state-owned company tasks are „to present to the public efficient, accurate and true information about world events, to familiarize the world community with life in Russia, to have a dialogue with compatriots abroad and to contribute to the promotion of Russian language and culture", there is no doubt that many of those interested in the proposed topics were tempted to give a like in order to get into the world full of mystery of yesterday and today Russian society. But, even from the first articles posted, it can be seen that Voice of Russia is a vehement critic of Romanian realities, advocating for a review of Bucharest policy, i.e. eloignment from the EU and the US and rapprochement with the Russian Federation. The analysis of posting on the Facebook page of the radio station Voice of Russia shows a huge outspoken wave of propaganda, meant to put pressure on decision-makers in Bucharest. It is also noted the trend of permanent administrators to spread ideas among the Romanians disappointed by the post-communist realities, but also among Euroskeptics and naïve people, seduced by a well-developed propaganda with subtle versions of persuasion.

Bellow, we shall take a look only at articles published on the website Voice of Russia at the category Romania and posted on the Facebook page of the radio station. The first was posted on 6 June 2012, when a reader Marian Radulescu, informs the editorial team on the initiative of Lukoil, which decided to build a church in Ploiesti. The church was completed in three months.

It is noteworthy that, in 2012, placing on-line of articles about Romania is extremely rare, one or two per month. There are, however, months and months when Romania appears to present no interest for the Voice of Russia. On 23 November 2012, an article stated: "Voice of Russia broadcasting company, the largest and oldest radio station in the 
world with broadcasts in foreign languages, was again attacked in Europe. State-owned Deutsche Welle accuses Voice of Russia that turns Romania into a banana republic, destructuring the rule of law and eloigning the country from Berlin and Bruxelles."

The first article (and only article in 2012), making public the interest of Voice of Russia, state-owned company, and therefore, the promoter of Kremlin's official policy, was published on December 6th and is entitled: How will tip the political balance in Romania? „We are certainly interested in the choice of the Romanian electorate and the direction in which the political vector of Romania' development will turn. In what direction it will be facing? Towards a peaceful neighborhood with Moldova or to the annexation, an idea supported by the president? From historical point of view, Russia is one of the bases of geopolitical Moldovan statehood. It is not any wonder that we do not like Basescu, a political radical with expansionist thoughts and insulting ideas against Russia's military history. He openly praises the Marshal Antonescu, a Nazi war criminal guilty of the deaths of thousands of Russians, Ukrainians, Moldavians, and Hebrew. For us, Basescu is a kind of variant of the Georgian President Saakashvili. I do not exclude that the current master from Cotroceni could lead the situation from the region to a military conflict with Transnistria, when the presence of Russian troops will be needed".

The article The end of primitive Russophobia was published on 28 December 2012, represented a discreet praise of the winners of parliamentary elections in Romania: „One of the great frustrations of the orange media is related to the alleged russophilism exhibited by the winners of parliamentary elections in Romania. Perhaps, according to the standards of Russophobic journalists in Bucharest, if a politician do not intend to swear Moscow every two minutes and refrain from publicly praising Marshal Antonescu, this politician is a so-called Moscow agent."

Since January 2013, the articles relating to the policy of Bucharest are multiplied considerably, so that by June 2014, we encounter an avalanche of articles on Romania (27 posting days, sometimes three articles per day). It could be said that, suddenly, Moscow rediscovered the political, geostrategic and economic importance of Romania and try by all means to cause a rift between Romania and its Western allies. As it is obviously that the Voice of Russia 
could not do this directly, because it was a well-known hotbed of Kremlin propaganda, the radio station began a campaign in a tabloid style, denying all the realities of Romania, exacerbating the "damage" and minimizing or even erasing the positive realities.

The first target was the then president of Romania, Traian Basescu, identified as the enemy from the very first articles posted in 1912. They turned aside on Basescu a rain of invective, insults, provocations, manipulations, showing the lack of elegance from the editor of the Voice of Russia. Let's look at some articles, in this regard, The White House and Traian Basescu - a completely unnatural relationship (21 January 2013); Romania's foreign policy or beyond the rabbit fence (28 January 2013); Basescu's Generals - political commissars of 50s? (30 March 2013); Nabucco failure is Traian Basescu's failure (28 June 2013); Basescu is playing with fire (13August 2013); Germany gave a slap to Basescu (8 January 2014); Traian Basescu - kaput (2 July 2014); Delirium of Cotroceni tenant (1 September 2014).

A second direction of the Voice of Russia was to blow the confidence of Romanian citizens in their own state. Obviously, there were enough problems, but the Voice of Russia exacerbates the situation in order to create a sense of panic. Tabloidization by presentation, headings and language: South Stream - the last train lost by Romania (8 January 2013); BNR - an institution for colonial administration (9 January 2013); Romania's economic collapse - forecast for 2013 (10 January 2013); Romania - pashalik of Washington (15 January 2013); Romania in war with itself (10 February 2013); Cypriot scenario in Romania? (1 April 2013); Romania's energy independence is only on paper (11 June 2013); Drifting Romania (31 May 2014); Eternal Romanian corruption (28 October 2014).

The third goal of the Voice of Russia was to show that Romania is isolated from the West, it is only a "colony" (the editors and collaborators have a real obsession for this word): Romania chooses selfisolation, vain hopes for CSAT (7 February 2013 ); Americans are ready to abandon Deveselu (11 February 2013); US abandon Eastern Europe (19 February 2013); Romania will never enter the Schengen (March 5, 2013); Romania will not join the euro area (14 March 2013); The prosperity of a country is given by domestic capital, not by transnational corporations (24 April 2013); Euroskeptics and Romanian skeptics (1 May 2013), from which we quote: "The fact that Romania cannot control the future and has no economic and political sovereignty is already well known. In a country where the 
US ambassador may throw in the bin the vote of millions of citizens, the discussions about political sovereignty are pointless"; Germany and Romanian colony (17 January 2014).

The last track of the Voice of Russia was to create among Romanians the psychosis of an inevitable war: Romania is preparing for war? (5 February 2013); US pushes Romania toward Russia (26 May 2013); The advice of Nobel Laureate for Romania: leaving the EU (31 May 2013); How Romanians incites the Ukrainian army (1 March 2014); The leader of the Russian Liberal Democratic Party Vladimir Zhirinovsky proposed to Poland, Hungary and Romania, NATO members, to take back their territories (21 March 2014); Romanian army compatible with NATO? (30 March 2914); Why Romania put strain on the situation in Transnistria? (22 April 2014); Romanian military mediocrity (30 April 2014); Bucharest rattle guns (12 May 2014), from which we quote: „What can we do when the economy is collapsing under our own eyes and the population no longer believes in a bright European future? In this challenge, Romanian politicians have found an answer, if not original, then at least one that has proven effectiveness over time: they decided to throw the country into a state of mass psychosis before the war."

The articles posted are obviously aimed at the Romanians but also the Romanians in Moldova, seeking to induce the idea that Bucharest wants the reunification by force, in fact, the annexation. Who are those posting comments? We can make a typology: Euroskeptics, convinced anticapitalists, nationalists, nostalgic communists, "notaffiliated", opponents of Kremlin ideas and usual Internet trolls making the handiwork of site. The articles are signed by: Valentin Mândrăşescu, Marian Rădulescu, a "reader" turned into a columnist and Internet troll, and ubiquitous Valentin Vasilescu," aviation pilot, former Deputy Commander of Otopeni Military Airport, degree in military science at the Academy of Military Studies in Bucharest in 1992", according to site presentation.

The style of pro-Russian Internet trolls is extremely violent, insulting the Romanian state institutions. They pretend to be concerned about the fate of Romania but most often emerges an obvious sympathy for Russia and its values, especially those related to power and politics. Pro-Russian Internet trolls attacks as "hounds” every critic: „I note that you have developed an obsession to argue with Russia because Russian does not want to enter into the club of international political and 
economic bastards. Russia does not want to apply the premeditated GENOCIDE on billions of Earth NORMAL inhabitants. Russia does not want especially to trigger a GLOBAL conflagration. Entering, however, into a speculation game, what makes you think that the Russian "solutions" would satisfy some people like you?” „You fucked up... Bulgaria will be well and you'll see that couple will make with Russia! They have a great mission together. As Vanga said, Bulgaria is the soul and Russia is the body. And it was more natural for Russians to trust Russophile Bulgarians but not the Russophobic Romanians."

Among those posting pro-Russia comments is Aurora Inoan, journalist, member of the Association of Strategic, Diplomatic, Economic, Cultural and Educational Cooperation with Russia and Slav Space (ACS-RSS), one of the channels of influence of Russia in Romania. She said in one of her postings: „More and more Romanian read or comment on VR or on other websites. [...] VR is an excellent site that brings much information from Russia and everywhere. Similarly, articles about the Romanian reality are (sic) written with skill, they are well documented, bring information bypassed by Romanian media, with few (sic) exceptions."

Watching the articles posted, we can identify the ardent supporters of Russia: Miruna, Uranus, Roman, Serban, True Mediocre and others.

Closing of the station on 25December 2014 resulted in a bunch of unemployed pro-Russian Internet trolls. Home Site of Voice of Russia remained at last posting, of 24 January 2015, 19.28 pm. The Facebook page continues its existence, but under the name Sputnik Italy. Cold War Propaganda proved its limits. Something more subtle will follow?

\section{References}

http://romanian.ruvr.ru/

https://www.facebook.com/VoceaRusiei?fref=ts. 


\section{Biodata}

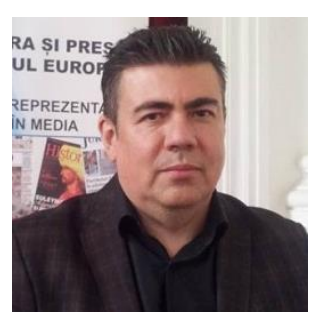

Faculty of Letters, „Dunărea de Jos” University, Galati, Romania.

Catalin NEGOITA was born on October $26^{\text {th }}$ 1963. He is lecturer PhD at Dunarea de Jos University - Faculty of Letters, Department of Journalism. Catalin Negoita is the author and coordinator of seven books, concerning both journalism and history.

Negoita, C. (2015). The Voice of Russia and the Romanian new media consumers. Logos Universality Mentality Education Novelty, Section: Social Sciences, IV (1), 113-121. 